\title{
Experimental assessment of a micro-pulse lidar system in comparison with reference lidar measurements for aerosol optical properties retrieval
}

\author{
Carmen Córdoba-Jabonero ${ }^{1}$, Albert Ansmann ${ }^{2}$, Cristofer Jiménez ${ }^{2}$, Holger Baars ${ }^{2}$, María-Ángeles López-Cayuela ${ }^{1}$, \\ and Ronny Engelmann ${ }^{2}$ \\ ${ }^{1}$ Instituto Nacional de Técnica Aeroespacial (INTA), Atmospheric Research and Instrumentation Branch, \\ Torrejón de Ardoz, 28850 Madrid, Spain \\ ${ }^{2}$ Leibniz Institute for Tropospheric Research (TROPOS), Leipzig, Germany
}

Correspondence: Carmen Córdoba-Jabonero (cordobajc@inta.es)

Received: 23 October 2020 - Discussion started: 31 October 2020

Revised: 2 June 2021 - Accepted: 18 June 2021 - Published: 30 July 2021

\begin{abstract}
Simultaneous observations of a polarized micropulse lidar (P-MPL) system and two reference European Aerosol Research Lidar Network lidars running at the Leipzig site Germany, $51.4^{\circ} \mathrm{N}, 12.4^{\circ} \mathrm{E} ; 125 \mathrm{~m}$ a.s.1.) were performed during a comprehensive 2-month field intercomparison campaign in summer 2019. An experimental assessment regarding both the overlap (OVP) correction of the PMPL signal profiles and the volume linear depolarization ratio (VLDR) analysis, together with its impact on the retrieval of the aerosol optical properties, is achieved; the experimental procedure used is also described. The optimal lidarspecific OVP function is experimentally determined, highlighting that the one delivered by the P-MPL manufacturer cannot be used long. Among the OVP functions examined, the averaged function between those obtained from the comparison of the P-MPL observations with those of the other two reference lidars seems to be the best proxy at both nearand far-field ranges. In addition, the impact of the OVP function on the accuracy of the retrieved profiles of the total particle backscatter coefficient (PBC) and the particle linear depolarization ratio (PLDR) is examined. The VLDR profile is obtained and compared with that derived from the reference lidar, showing that it needs to be corrected by a small offset value with good accuracy. Once P-MPL measurements are optimally (OVP, VLDR) corrected, both the PBC and PLDR profiles can be accurately derived and are in good agreement with reference aerosol retrievals. Overall, as a systematic requirement for lidar systems, an adequate OVP function deter-
\end{abstract}

mination and VLDR testing analysis needs to be performed on a regular basis to correct the P-MPL measurements in order to derive suitable aerosol products. A dust event observed in Leipzig in June 2019 is used for illustration.

\section{Introduction}

Active remote sensing is an excellent tool for vertical monitoring of the atmosphere. In particular, aerosol lidar systems have demonstrated to be suitable instrumentation for aerosol and cloud profiling in both the troposphere and stratosphere (e.g. Amiridis et al., 2015; Baars et al., 2019). Tropospheric aerosols are usually confined up to $7-8 \mathrm{~km}$ height under aerosol intrusion conditions (e.g. Mattis et al., 2008; Pappalardo et al., 2013); otherwise, they are mostly concentrated in the ABL (around less than $1.5 \mathrm{~km}$ height). Indeed, lidar systems are widely used due to their high vertical spatial and temporal resolution.

Ground-based lidar networks are widely operative within the GAW (Global Atmospheric Watch) Aerosol LIdar Observations Network (GALION); among them, there are those extended at continental scales, such as EARLINET (European AeRosol LIdar NETwork; Pappalardo et al., 2014), which also belongs to the Aerosol Cloud and Trace Gases Research Infrastructure (ACTRIS), AD-NET (Asian Dust and aerosol lidar observation network; Sugimoto et al., 2008), and LALINET (aka ALINE, Latin American Li- 
dar NETwork; Barbosa et al., 2014). In addition, there are other aerosol networks like MPLNET (Micro-Pulse Lidar NETwork; Welton et al., 2001) within GAW/GALION and PollyNET (POrtabLe Lidar sYstem NETwork; Baars et al., 2016), operated as a part of EARLINET, whose sites are distributed around the world.

The use of the lidar observations with polarization capabilities is increasing as the lidar depolarization measurements allow a better aerosol speciation (dust, marine aerosol, anthropogenic pollution, volcanic ash, biomass burning, pollen, etc.) as well as the separation of the optical properties (backscatter, extinction) of particle components within complex aerosol mixtures with vertical resolution (e.g. Tesche et al., 2009; Ansmann et al., 2011; Burton et al., 2014; Yu et al., 2015; Córdoba-Jabonero et al., 2018; Bohlmann et al., 2019). Therefore, new and promising methods based on the particle depolarization ratio were developed and used to derive aerosol profiles in terms of particle mass concentration separately for the coarse and fine modes (e.g. Mamouri and Ansmann, 2017) and to estimate both the cloud-condensation nuclei $(\mathrm{CCN})$ and ice-nucleating particle (INP) concentrations (e.g. Mamouri and Ansmann, 2016).

The atmospheric lidar scanning provides an accurate characterization at all ranges; however, lidar systems present an incomplete response in the near-range observational field due to the partial intersection of the field of view between the transmitter and the receiver for both the biaxial and coaxial lidar configurations. Therefore, lidar signal profiles must be corrected by this near-field loss of signal, that is, the overlap (OVP) correction (Wandinger and Ansmann, 2002). The full OVP height depends on the lidar system (e.g. Wandinger et al., 2016).

During the last two decades, micro-pulse lidar (MPL) systems (Campbell et al., 2002; Welton and Campbell, 2002; manufacturer: Sigma Space Corp., currently Droplet Measurement Technologies) were deployed at different latitudes and many of them in the frame of MPLNET; in the last few years, a polarized MPL version (P-MPL) is the standard lidar system in this network. Both MPL and P-MPL observations have been widely performed for continuous monitoring of aerosols and clouds. In particular, MPL/PMPL measurements were used for atmospheric boundary layer (ABL) height retrievals (Lewis et al., 2013; Toledo et al., 2014, 2017), detection and characterization of both cirrus clouds (Campbell et al., 2016; Lewis et al., 2016; Córdoba-Jabonero et al., 2017; Lolli et al., 2017; Campbell et al., 2021) and polar stratospheric clouds (PSCs) (Campbell and Sassen, 2008; Córdoba-Jabonero et al., 2013), depolarization-based characterization of the optical properties of different aerosol mixtures (Sicard et al., 2016; Córdoba-Jabonero et al., 2016, 2018), aerosol mass concentration estimation either in synergy with airborne measurements (Córdoba-Jabonero et al., 2016) or in comparison with forecast model simulations (Córdoba-Jabonero et al., 2019), determination of the precipitation intensity (Lolli et al., 2018,
2020) and cloud thermodynamic phase (Lewis et al., 2020), and assessment of the radiative effect of aerosols and cirrus clouds (Campbell et al., 2016; Lolli et al., 2017; CórdobaJabonero et al., 2020, 2021; Campbell et al., 2021; Sicard et al., 2021), among other things. These studies demonstrated good MPL performance in aerosol and cloud research. The P-MPL is an elastic coaxial single-wavelength $(532 \mathrm{~nm})$ system and, different from older MPL versions (Campbell et al., 2002; Welton and Campbell, 2002), incorporates depolarization capabilities (Flynn et al., 2007). As a value-added improvement, it can operate in routine continuous (24/7) mode. However, the P-MPL system needs to be well characterized in terms of the backscattered lidar signal detected by both depolarization channels of the instrument (Flynn et al., 2007; Welton et al., 2018) in order to retrieve plausible aerosol optical properties. In particular, due to the very narrow telescope field of view, the lidar system reaches the full OVP height at relatively high altitudes (typically at $4-6 \mathrm{~km}$ height; Campbell et al., 2002), which is particularly relevant for tropospheric aerosol research. For this reason, an accurate overlap correction, among other features, is needed for MPL systems.

MPLNET have established methods for overlap calibration, as those described in Berkoff et al. (2003). They are based on either performing measurements under atmospheric stable and homogeneous conditions with the MPL pointing in the horizontal direction or making use of a secondary wide field-of-view receiver (WFR) telescope. However, both of them could not yet be applied on the site of the MPL system examined in this study. Hence, an alternative experimental procedure for the OVP function determination is introduced in this work, which is based on the cross-comparison of the backscattered signal recorded by the uncorrected lidar system (our MPL) with respect to that collected by a reference (overlap-corrected) lidar. A similar methodology has been also used for the overlap correction of other lidars and ceilometers (e.g. Guerrero-Rascado et al., 2010; Sicard et al., 2020; and references therein). In this framework, an experimental campaign was planned at the EARLINET Leipzig, site (Germany) and, in particular, devoted to simultaneously comparing the observations of a P-MPL system with reference well-calibrated lidar measurements in order to determine the required P-MPL performance.

The aim of this work is threefold: (1) to achieve an OVP correction of a P-MPL system, i.e. to estimate the experimental OVP function for correcting the P-MPL measurements; (2) to evaluate the volume linear depolarization ratio (VLDR), which is a lidar-derived parameter independent of OVP correction; and (3) to determine the P-MPL correction-induced effects on the retrieval of optical properties, including both the height-resolved particle backscatter coefficient (PBC) and particle linear depolarization ratio (PLDR). Section 2 introduces the methodology for that purpose: an overview of the field intercomparison campaign performed, a brief description of both the P-MPL and reference lidar systems used, and the experimental approaches applied 
for the data analysis regarding the experimental estimation of the OVP function of the P-MPL system (error processing is described in Appendix A), the evaluation of the VLDR, and the retrieval of the particle optical properties. Results are presented in Sect. 3. A dust case observed during the field campaign is used for that purpose. The main conclusions are presented in Sect. 4.

\section{Methodology}

\subsection{Field campaign overview}

During a field campaign carried out at the EARLINET station at Leipzig, Germany (51.35 $\mathrm{N}, 12.43^{\circ} \mathrm{E} ; 125 \mathrm{~m}$ a.s.l.), managed by the Leibniz Institute for Tropospheric Research (TROPOS) for 6 weeks in June-July 2019, the performance of a P-MPL system was experimentally examined with a special emphasis on the OVP correction and VLDR evaluation. The lidar system used was the MPL44245 unit (formerly Sigma Space Corp., currently Droplet Measurement Technologies) routinely operating at the MPLNET/El Arenosillo station sited at Huelva, Spain (ARN/Huelva, $37.1^{\circ} \mathrm{N}, 6.7^{\circ} \mathrm{W} ; 40 \mathrm{~m}$ a.s.1.), which is managed by the Spanish Institute for Aerospace Technology (INTA). Both stations are also AERONET (AErosol RObotic NETwork) sites, accomplishing the requisite for co-location of both networks for the elastic retrieval of the aerosol optical properties. For the campaign, this P-MPL was temporarily deployed outside MPLNET at Leipzig to be compared against two EARLINET lidars routinely operative in this station as Polly (POrtabLe Lidar sYstem; Althausen et al., 2009; Engelmann et al., 2016) and MARTHA (Multiwavelength Tropospheric Raman lidar for Temperature, Humidity, and Aerosol profiling; Jimenez et al., 2018) systems. They were used as reference because these lidars are well characterized with respect to EARLINET quality assurance standards (e.g. Böckmann et al., 2004; Pappalardo et al., 2004; Freudenthaler et al., 2008; Pappalardo et al., 2014; Wandinger et al., 2016; Belegante et al., 2018; Granados-Muñoz et al., 2016; Freudenthaler et al., 2016).

\subsection{Lidar systems}

\subsubsection{Polarized micro-pulse lidar (P-MPL)}

The P-MPL system (Sigma Space Corp./Droplet Measurement Technologies, version MPL-4B) is the standard lidar currently operating within MPLNET. It is an elastic lidar in coaxial configuration with depolarization capabilities operating in full-time (24/7) mode. Among the principal optical features, the $\mathrm{Nd}-\mathrm{YVO}_{4}$ laser emission at $532 \mathrm{~nm}$ with a pulse energy of $6-8 \mu \mathrm{J}$ and a repetition rate of $2500 \mathrm{~Hz}$ is recorded by a unique avalanche photodiode detector (APD), the receiver system presents a field of view (FOV) of $80 \mu \mathrm{rad}$ full angle, and the telescope diameter is $18 \mathrm{~cm}$ wide (Sigma
Space Corp.: MPL system information handbook, 2018). PMPL vertical profiles are routinely acquired with $1 \mathrm{~min}$ integrating time and $15 \mathrm{~m}$ vertical resolution (in particular, for the ARN/Huelva P-MPL system) up to $30 \mathrm{~km}$ height. The main instrumental features of the P-MPL system are shown in Table 1.

The optical layout of the MPL-4B version is schematically shown in Fig. 1 of Flynn et al. (2007). The laser light is alternatively transmitted linearly and circularly polarized to the atmosphere by switching between two retardation modes of a ferroelectric liquid crystal (FLC) rotator. The corresponding backscattered light to the two polarized states by passing through a beam splitter to the single APD is recorded depending on the polarizing or depolarizing atmospheric particles leading to the suppression or not, respectively, of the orthogonally detected signal with respect to the transmitted one into the single APD. The two polarized signals are semisimultaneously detected by alternatively switching on the basis of $50 \% / 50 \%$ of the FLC polarization mode within every integrating minute. Note that the P-MPL pulse frequency is $2500 \mathrm{~Hz}$ and the polarization state is switched every 250 pulses but just 249 pulses are collected since one of the pulses is discarded during the FLC switching time $(\sim 100 \mu \mathrm{s})$. That is, the two signals are alternatively detected by the same APD and are recorded in two polarized channels, i.e. the $532 \mathrm{~nm}$ cross-signal $\left(P_{\text {cross }}\right)$ and the $532 \mathrm{~nm}$ co-signal $\left(P_{\text {co }}\right)$ (for a more detailed description see Flynn et al., 2007). Therefore, since there are no potentially existing efficiency or alignment differences between the two signal-channels (as used a single APD), no corrections for these effects are required, as is typically needed for ordinary two-channel polarization lidars. Particular regular calibrations and signal processing were applied, which are the same as those described by Campbell et al. (2002) and Welton and Campbell (2002) and also by Flynn et al. (2007), whose data processing techniques also remain applicable for P-MPL systems, as indicated by Welton et al. (2018). Therefore, the measured lidar signal in the two polarized channels is used to derive both the P-MPL total range-corrected signal (RCS), $P^{\mathrm{MPL}}$, and the volume linear depolarization ratio (VLDR), $\delta^{\mathrm{V}}$, by adapting the methodology as described in Flynn et al. (2007), that is

$$
\begin{aligned}
& P^{\mathrm{MPL}}=P_{\text {co }}+2 P_{\text {cross }}, \text { and } \\
& \delta^{\mathrm{V}}=\frac{P_{\text {cross }}}{P_{\text {co }}+P_{\text {cross }}} .
\end{aligned}
$$

This data processing has been successfully applicable in previous studies (e.g. Sicard et al., 2016; Córdoba-Jabonero et al., 2018; Lewis et al., 2020), independently of those established in MPLNET. Among the required routine instrumental P-MPL corrections (Campbell et al., 2002; Welton and Campbell, 2002), the OVP is a concerning issue since the typical full OVP height is reached at rather high altitudes (usually at $4-5 \mathrm{~km}$ height), thus affecting the aerosol profiles at ranges in the overall boundary layer and part of the 
Table 1. Main instrumental features of the lidar systems.

\begin{tabular}{llll}
\hline Lidar system & P-MPL & Polly & MARTHA \\
\hline $\begin{array}{l}\text { Routine operation } \\
\text { Lidar networks }\end{array}$ & $24 / 7$ & $24 / 7$ & Supervised \\
\hline Transmitter properties & & EARLINET & EARLINET \\
\hline Wavelength (nm) & 532 & $532^{*}$ & $532^{*}$ \\
Energy/pulse (mJ) & $0.006-0.008$ & 400 & 1000 \\
Pulse frequency $(\mathrm{Hz})$ & 2500 & 20 & 30 \\
Eye safety & Yes (ANSI Class II) & No & No \\
\hline Receiver properties & & & \\
\hline Telescope diameter $(\mathrm{cm})$ & 18 & 30 & 80 \\
Telescope focal length $(\mathrm{m})$ & 2.23 & 0.89 & 9 \\
FOV ( $\mu$ rad full angle) & 80.4 & 1000 & 500 \\
\hline Depolarization & Yes & Yes & Yes \\
Raman detection & No & Yes & Yes \\
\hline
\end{tabular}

${ }^{*}$ Used in this study.

troposphere. Hence, an important issue to be achieved is the particular overlap correction function for this particular PMPL system. After purchase, the P-MPL system is delivered with an original OVP function as provided by the manufacturer company (formerly Sigma Space Corp., currently Droplet Measurement Technologies), which, however, must be re-evaluated with time. Indeed, one of the goals of this work is to show the experimental procedure, similarly to others (e.g. Guerrero-Rascado et al., 2010; Sicard et al., 2020), to obtain a new OVP function for the P-MPL lidar as compared to the original function (see Sect. 2.3.1), together with examining its effects on the retrieval of the optical properties.

\subsubsection{POrtabLe Lidar sYstem (Polly)}

The EARLINET Polly (POrtabLe Lidar sYstem) lidars are sophisticated, automated Raman-polarization lidar systems for scientific purposes but with the advantage of being an easy-to-use and well-characterized instrument with the same design, automated operation, and centralized data processing delivering near-real-time data products. Polly systems have been developed and constructed at TROPOS with international partners since 2002 (Engelmann et al., 2016). All Polly lidar systems are designed for automatic and unattended operation in 24/7 mode. Twelve Polly lidar systems are distributed around the globe (Baars et al., 2016). The Polly lidar system used as a reference in this comparison analysis is the first one of the Polly family (Engelmann et al., 2016), which was substantially upgraded in 2016 (version Polly_1v2). It emits linearly polarized light at $532 \mathrm{~nm}$ with five receiver channels: elastically backscattered light at $532 \mathrm{~nm}$, cross-polarized light at $532 \mathrm{~nm}$, co-polarized light at $532 \mathrm{~nm}$, rotational Raman scattered light near $532 \mathrm{~nm}$, and vibrational-rotational Raman scattered light at $607 \mathrm{~nm}$. Its full OVP is reached at around $300-500 \mathrm{~m}$ height and thus preferred for the P-MPL OVP correction purpose. Profiles of the Polly range-corrected signal, $P^{\text {Polly }}$, are routinely derived using sample settings with $7.5 \mathrm{~m}$ vertical resolution and $30 \mathrm{~s}$ temporal integration. The main instrumental features of the Polly system are shown in Table 1.

\subsubsection{Multiwavelength Atmospheric Raman lidar for Temperature, Humidity, and Aerosol profiling (MARTHA)}

The second EARLINET lidar, which is used as a reference in this work, is the dual receiver field of view (RFOV) Multiwavelength Atmospheric Raman lidar for Temperature, Humidity, and Aerosol profiling (MARTHA) (Mattis et al., 2008; Schmidt et al., 2013; Jimenez et al., 2019). MARTHA has a powerful laser, transmitting in total $1 \mathrm{~J}$ per pulse at a repetition rate of $30 \mathrm{~Hz}$ with an $80 \mathrm{~cm}$ telescope diameter and is thus well designed for tropospheric and stratospheric aerosol observations. This lidar system measures Raman signals at $532 \mathrm{~nm}\left(P^{\text {MARTHA }}\right.$, which is used in this work) and $607 \mathrm{~nm}$ as well as the polarizationsensitive $532 \mathrm{~nm}$ backscatter signals at two RFOVs so that, besides aerosol profiles, cloud microphysical properties can be retrieved from measured cloud multiple scattering effects. MARTHA can provide the $532 \mathrm{~nm}$ particle depolarization ratio as measured with the smaller RFOV and also the 355 , 532, and $1064 \mathrm{~nm}$ particle backscatter coefficients and the 355 and $532 \mathrm{~nm}$ extinction coefficient profiles with their corresponding lidar ratio profiles. For this large telescope (and a selected receiver FOV of $0.5 \mathrm{mrad}$ ), the overlap between the laser beam and receiver FOV is complete around $2000 \mathrm{~m}$ height. The overlap profile of this laboratory lidar is very sta- 
ble. The main instrumental features of the MARTHA system are shown in Table 1.

\subsection{Experimental estimation of the overlap (OVP) function}

The overlap (OVP) function, $F_{\mathrm{OVP}}$, is used to correct the $\mathrm{P}$ MPL (no OVP-corrected) RCS profiles, $P^{\mathrm{MPL}}(z)$, obtained from Eq. (1), at near-field altitudes, that is

$P_{\mathrm{OVP}}^{\mathrm{MPL}}(z)=P^{\mathrm{MPL}}(z) / F_{\mathrm{OVP}}(z)$,

where $P_{\mathrm{OVP}}^{\mathrm{MPL}}(z)$ represents the overlap-corrected P-MPL RCS profiles.

In this work, the experimental procedure to obtain $F_{\mathrm{OVP}}$ is based on the comparison of the $P^{\mathrm{MPL}}(z)$ to either the Polly RCS profiles, $P^{\text {Polly }}(z)$, or the MARTHA profiles, $P^{\text {MARTHA }}(z)$, which are both used as reference under relatively clean and mostly clear conditions. The Polly and MARTHA lidars present the advantage in contrast to PMPL system that the OVP function can be experimentally determined using their Raman channels (Wandinger and Ansmann, 2002). The P-MPL overlap function is thus calculated in terms of the ratio between the P-MPL and Polly/MARTHA RCS profiles, i.e.

$$
F_{\mathrm{OVP}}(z)=P^{\mathrm{MPL}}(z) / P^{\mathrm{ref}}(z),
$$

where $P^{\text {ref }}(z)$ denotes the reference RCS profiles as obtained from either Polly, $P^{\text {Polly }}(z)$, or MARTHA, $P^{\text {MARTHA }}(z)$, measurements. Both sets of RCS profiles are normalized at a given height (higher than the OVP altitude range under aerosol-free conditions), $z_{\text {norm}}$, and then $F_{\mathrm{OVP}}(z)$ can be derived using Eq. (3). In particular, the full OVP is conservatively obtained at the normalization height $z_{\text {norm }}=$ $9.5 \mathrm{~km}$ a.g.l., which is $F_{\mathrm{OVP}}(z)=1$ at $z \geq z_{\text {norm }}$. Errors associated with the estimation of $F_{\mathrm{OVP}}(z)$ using this experimental approach are described in Appendix A. Night-time lidar observations performed under relatively clean conditions at the Leipzig station (AERONET AOD $<0.1$ and $\mathrm{AE}>1.2$ ) were used for the P-MPL OVP determination. In particular, two time periods were selected in coincidence with either Polly or MARTHA observations in order to provide an extended comparison analysis using diverse reference lidar systems under different lidar operational conditions.

\subsection{Retrieval of the aerosol optical properties: particle backscatter coefficient and both volume and particle linear depolarization ratios}

Once the OVP-corrected RCS is obtained from Eq. (3), the particle backscatter coefficient (PBC), $\beta_{\mathrm{p}}\left(\mathrm{km}^{-1} \mathrm{sr}^{-1}\right)$, can be derived applying the Klett-Fernald (KF) algorithm (Fernald, 1984; Klett, 1985) by constraining the lidar ratio (LR; extinction-to-backscatter ratio) with the AERONET aerosol optical depth (AOD) (elastic KF solution) (Marenco et al., 1997); hence, an effective LR, $S_{\mathrm{a}}^{\text {eff }}$, is also obtained after convergence.

The particle linear depolarization ratio (PLDR), $\delta_{\mathrm{p}}$, can be determined as follows:

$\delta_{\mathrm{p}}=\frac{R \delta^{\mathrm{V}}\left(1+\delta_{\mathrm{mol}}\right)-\delta_{\mathrm{mol}}\left(1+\delta^{\mathrm{V}}\right)}{R\left(1+\delta_{\mathrm{mol}}\right)-\left(1+\delta^{\mathrm{V}}\right)}$,

where $R$ is the backscattering ratio $\left(R=\frac{\left(\beta_{m}+\beta_{\mathrm{p}}\right)}{\beta_{\mathrm{m}}}\right.$, with $\beta_{\mathrm{m}}$ being the molecular backscattering coefficient), $\delta^{\mathrm{V}}$ is the volume linear depolarization ratio (VLDR), and $\delta_{\mathrm{mol}}$ is the molecular depolarization ratio. For P-MPL systems, $\delta_{\mathrm{mol}}=$ 0.0037 , which is almost independent of atmospheric temperature (relative uncertainty $<0.1 \%$ ), as their FWHM is less than $0.2 \mathrm{~nm}$ (Behrendt and Nakamura, 2002). The PLDR is a lidar parameter widely used for defining the aerosol type (Burton et al., 2012; Groß et al., 2013) and for discriminating the particle size mode in some aerosol mixtures (Mamouri and Ansmann, 2017; Córdoba-Jabonero et al., 2018), among others. The determination of PBC mainly depends on the OVP correction, as will be discussed in Sect. 3.3; hence, the PLDR is also affected by OVP. Therefore, a good knowledge of the OVP function for the specific P-MPL system is also needed to obtain high-quality PBC and PLDR profiles.

The volume linear depolarization ratio (VLDR), $\delta^{\mathrm{V}}$, can be determined in relation with the P-MPL depolarization ratio, $\delta^{\mathrm{MPL}}$ (Mishchenko and Hovenier, 1995; Gimmestad, 2008). Looking at the formulae shown in Eq. 1.8 in Flynn et al. (2007), $\delta^{\mathrm{V}}$ can be easily expressed as

$\delta^{\mathrm{V}}=\frac{\delta^{\mathrm{MPL}}}{\delta^{\mathrm{MPL}}+1}=\frac{P_{\text {cross }}}{P_{\text {co }}+P_{\text {cross }}}$,

i.e. Eq. (2) is obtained, where $\delta^{\mathrm{MPL}}$ is defined as the ratio between $P_{\text {cross }}$ and $P_{\text {co }}$ (the two polarized RCSs, as described in Sect. 2.2.1). Since the OVP function is equally applied to both signals, the VLDR is unaffected by the OVP correction; however, it actually affects, together with the PBC, the PLDR estimation (see Eq. 5). Therefore, the VLDR for the P-MPL system was also experimentally evaluated in comparison with that derived from Polly lidar measurements, for instance, similarly to the approach shown by CórdobaJabonero et al. (2013). This experimental polarization correction is based on real measurements as an alternative (see Sect. 3.2), due to the unavailability of applying the special and specific methods for polarization calibration within MPLNET, as those described in Welton et al. (2018).

All the variables are height resolved, but the altitude dependence is omitted for simplicity. A dust case occurring for the night of 29-30 June 2019 at the Leipzig station is selected for that purpose (in particular, the dust intrusion observed over Leipzig in June 2019 is widely characterized in Córdoba-Jabonero et al., 2021). 


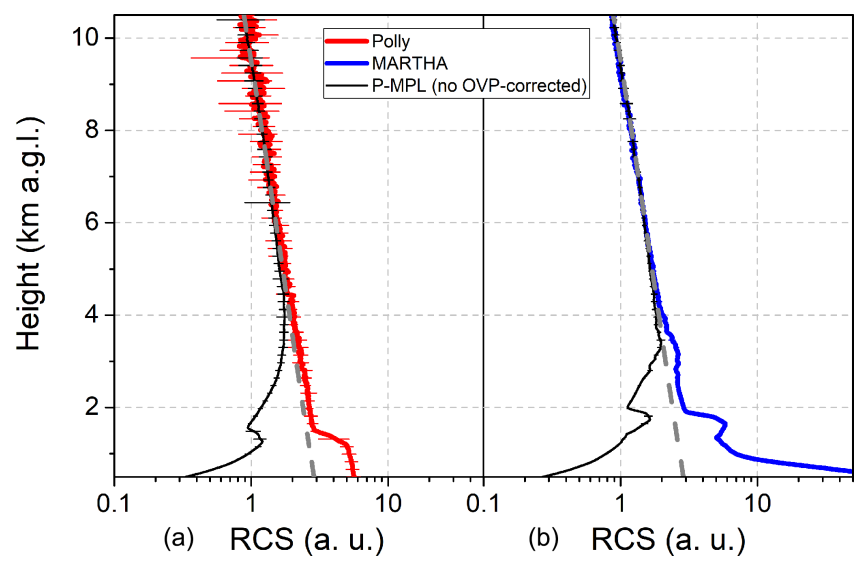

Figure 1. Comparison of the normalized reference (a) Polly (red line; for clarity, the 12 P-MPL and Polly RCS profiles from 28 June 18:00 UT to 29 June 05:00 UT were averaged) and (b) MARTHA (blue line; 4 P-MPL and MARTHA RCS profiles from 23 July 21:00 UT to 24 July 00:00 UT were averaged) with respect to the uncorrected by overlap P-MPL profiles (black lines). Normalization height at $9.5 \mathrm{~km}$ a.g.l. The aerosol-free background signal is shown by a grey dashed line.

\section{Results}

\subsection{Experimental overlap function $F_{O V P}$}

P-MPL observations were carried out from 6 June to 26 July 2019 at the Leipzig station during the field campaign. Simultaneous P-MPL and Polly/MARTHA measurements as performed under relatively clean conditions were selected for estimating the OVP function. The first comparison analysis corresponded to 12-hourly averaged P-MPL and Polly RCS profiles within the night-time period from 28 June 2019 at 18:00 UT to 29 June 2019 at 05:00 UT (daytime values on 28 June at 18:00 UT: AOD $=0.10$, Ångstrom exponent $\mathrm{AE}=1.59)$. The second comparison was related to the MARTHA night-time RCS measurements as averaged for $4 \mathrm{~h}$ from 23 July 2019 at 21:00 UT to 24 July 2019 at 00:00 UT (daytime values on 23 July at 18:00 UT: $\mathrm{AOD}=0.09, \mathrm{AE}=$ 1.33); P-MPL RCS profiles were also averaged during that same period for comparison. Figure 1 shows the uncorrected by overlap P-MPL RCS profiles in comparison with the reference Polly (left panel) and MARTHA (right panel) profiles for both of those particular periods. The part of the P-MPL RCS profiling to be OVP-corrected is clearly highlighted, ranging from the surface up to around $6 \mathrm{~km}$ height. Next, the experimental estimation of $F_{\mathrm{OVP}}$ for the P-MPL system is analysed in terms of the OVP-corrected RCS as obtained by applying each of the experimentally estimated $F_{\mathrm{OVP}}^{\text {Polly }}$ and $F_{\text {OVP }}^{\text {MARTHA }}$ (see Sect. 2.3.1), also including a comparison with the original one, $F_{\mathrm{OVP}}^{\text {original }}$ (as provided by the manufacturer).

Figure 2 shows the experimental OVP functions, $F_{\mathrm{OVP}}(z)$, as obtained from the comparison of the P-MPL RCS profiles

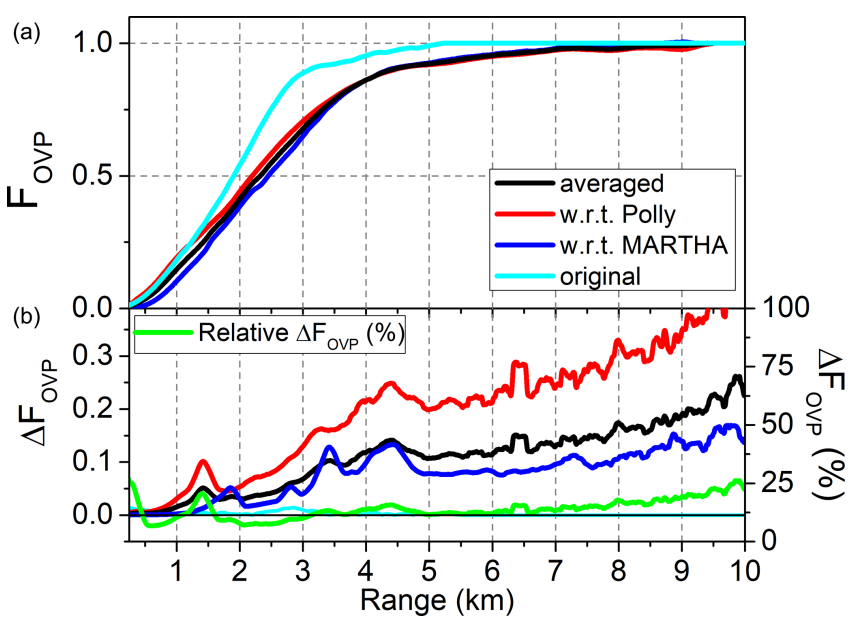

Figure 2. (a) Experimental overlap functions, $F_{\mathrm{OVP}}$, as obtained for two different days from the ratio between the P-MPL RCS profiles with respect to the Polly ( $F_{\text {OVP }}^{\text {Polly }}$, red $)$ and MARTHA $\left(F_{\text {OVP }}^{\text {MARTA }}\right.$, blue) profiles, together with the averaged function $\left(F_{\mathrm{OVP}}^{\mathrm{av}}\right)$ of both of them (black line); the original overlap function as provided by the manufacturer, $F_{\text {OVP }}^{\text {original }}$, is also included (cyan line). (b) Errors, $\Delta F_{\mathrm{OVP}}$, associated with the OVP function estimation for each comparison case: P-MPL with respect to Polly (red), P-MPL with respect to MARTHA (blue), and the averaged OVP function of both of them (black); the error for $F_{\mathrm{OVP}}^{\text {original }}$ (cyan) and the relative error for $F_{\mathrm{OVP}}^{\mathrm{av}}$ (green line) are also included.

with respect to Polly and MARTHA lidar measurements (top panel: $F_{\mathrm{OVP}}^{\text {Polly }}$ in red and $F_{\mathrm{OVP}}^{\mathrm{MARTHA}}$ in blue) (see Eq. 4 ) together with $F_{\mathrm{OVP}}^{\text {original }}$; the associated errors are also shown in the bottom panel. In addition, as both of the OVP functions were obtained on two different days, temperature-related changes could be produced in the OVP estimation. Hence, the averaged $F_{\mathrm{OVP}}^{\mathrm{av}}(z)$ between both OVP functions is also calculated and shown together with the absolute and relative errors in Fig. 2 (top and bottom panels, respectively). Details on the OVP error processing are described in Appendix A. By comparing with the original OVP function, large discrepancies can be clearly observed, highlighting the change of $F_{\mathrm{OVP}}(z)$ with time, mostly in the relevant $1-5 \mathrm{~km}$ height range. Regarding the OVP functions $F_{\mathrm{OVP}}^{\text {Polly }}$ and $F_{\mathrm{OVP}}^{\text {Martha }}$, differences are also found, mostly in the near-field range up to around $3 \mathrm{~km}$ height. However, by using $F_{\mathrm{OVP}}^{\mathrm{av}}(z)$ instead of one of two others for P-MPL RCS correction, its relative error is just $14 \pm 5 \%$ on average from 0.3 up to $10 \mathrm{~km}$ height (see Fig. 2, bottom). Taking into account these errors, $F_{\mathrm{OVP}}^{\mathrm{av}}(z)$ can be the OVP function used for correcting the P-MPL RCS profiles at near-field heights, following the expression in Eq. (3), as it seems to be the best proxy for OVP correction of the P-MPL RCS profiles.

The previous uncorrected and OVP-corrected P-MPL RCS profiles using both $F_{\mathrm{OVP}}^{\mathrm{av}}$ and $F_{\mathrm{OVP}}^{\text {original }}$ are shown in Fig. 3 . Slight differences are observed for the P-MPL RCS pro- 


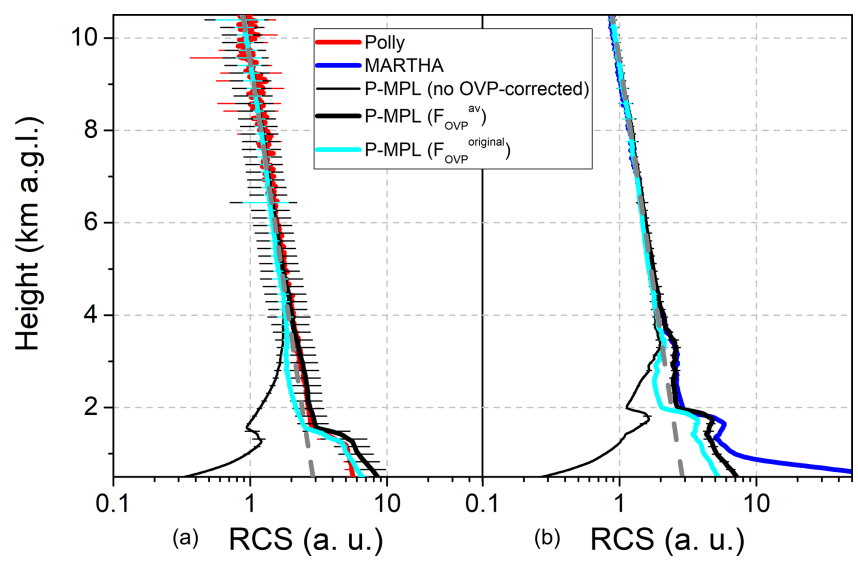

Figure 3. OVP-corrected (black thick lines) P-MPL RCS profiles using the $F_{\mathrm{OVP}}^{\mathrm{av}}$ function and the uncorrected RCS profiles (black thin lines) with respect to (a) Polly (red line) and (b) MARTHA (blue line) RCS profiles, together with the OVP-corrected profiles using $F_{\mathrm{OVP}}^{\text {original }}$ (cyan lines).

files as compared to the Polly and MARTHA ones using $F_{\mathrm{OVP}}^{\text {av }}$, despite it being calculated from averaging $F_{\mathrm{OVP}}^{\text {Polly }}$ and $F_{\text {OVP }}^{\mathrm{MARTHA}}$, which were obtained from measurements on different days (only about one month between them). Large differences are clearly found when $F_{\mathrm{OVP}}^{\text {original }}$ is applied, mostly between 1.5 and $3 \mathrm{~km}$ height, showing that the OVP function as provided by the manufacturer is not applicable for aerosol research after some time, being necessary to regularly determine a OVP function, as performed and described in this work. Once the P-MPL RCS profiles are OVP-corrected, the optical properties of the aerosols can be retrieved using inversion algorithms. OVP-induced effects on the inversion of the aerosol optical properties are analysed in Sect. 3.3.

\subsection{Volume linear depolarization ratio (VLDR)}

Before analysing the OVP impact on the retrieval of the aerosol optical properties, the VLDR is also examined. As stated before, despite the VLDR being unaffected by the OVP correction, it actually affects, together with the PBC, $\beta_{\mathrm{p}}$, the PLDR, $\delta_{\mathrm{p}}$, estimation (see Sect. 2.4).

The P-MPL VLDR is calculated using Eq. (6) and compared with that derived from Polly measurements as reference, since TROPOS follows all quality assurance efforts regarding polarization lidar calibration tests in the Polly systems as recommended by EARLINET (Freundenthaler et al., 2008, 2016). A dust outbreak case observed at the Leipzig site for the night on 29-30 June 2019 is examined for that purpose. Figure 4 shows the VLDR as obtained from both the $\delta_{\mathrm{MPL}}^{\mathrm{V}}$ and $\delta_{\text {Polly }}^{\mathrm{V}}$ profiles as averaged from 18:00 to 23:00 UT on 29 June and from 00:00 to 05:00 UT on 30 June (for clarity, only averaged $\delta^{\mathrm{V}}$ profiles are shown). The dust signature is clearly marked, showing a dust layer clearly confined between 3 and $6 \mathrm{~km}$ height, with a higher variability for the

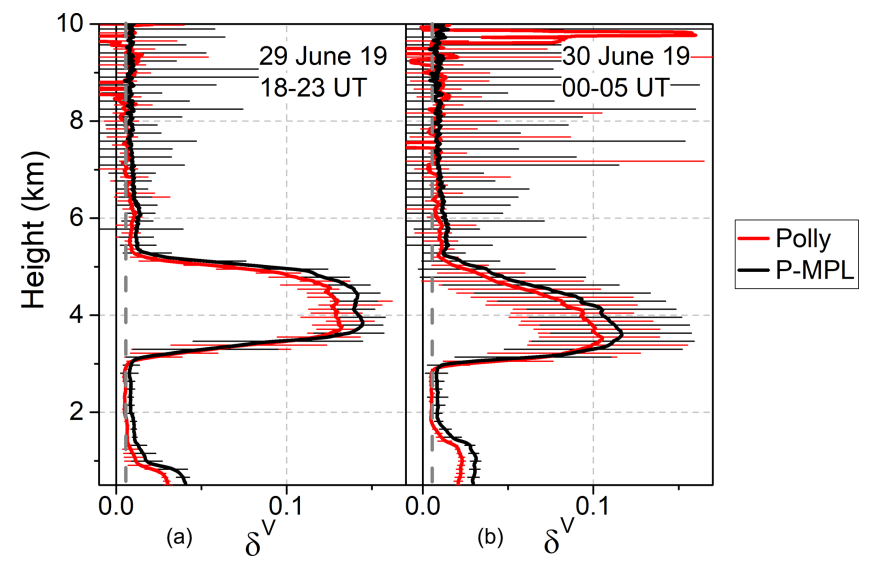

Figure 4. Volume linear depolarization ratio (VLDR), $\delta^{\mathrm{V}}$, as obtained from both the P-MPL (black line) and Polly (15-p smoothed red line) measurements carried out on: (a) 29 June 2019, as averaged from 18:00 to 23:00 UT and (b) 30 June 2019, as averaged from 00:00 to 05:00 UT (error bars are also shown in black and red, respectively). The aerosol-free background $\delta \mathrm{V}$ is marked by a grey dashed line.

second interval due to the decay of dusty conditions at the end of that period, as reflected by a larger error uncertainty in time averaging. Overall, despite $\delta_{\mathrm{MPL}}^{\mathrm{V}}$ values seeming to be higher than those of $\delta_{\text {Polly }}^{\mathrm{V}}$, peaking between 0.11 and 0.14 in the dust layer, they are within the error range. Hence, the VLDR was averaged within several aerosol-free height intervals below and above that defined dust layer to analyse potential changes and offsets. The mean $\delta^{\mathrm{V}}$ values (and their standard deviation, SD) are shown in Table 2.

Looking at the results, $\delta_{\text {Polly }}^{\mathrm{V}}$ presents larger errors than those for $\delta_{\mathrm{MPL}}^{\mathrm{V}}$, because it is associated with a lower signalto-noise ratio as height increases for the Polly measurements (no smoothing applied). This is reflected by the higher relative error (\%SD) found for the Polly VLDR $(23 \%)$ with respect to that for the P-MPL $(6 \%)$ when all the aerosolfree height intervals are considered. Mean $\delta^{\mathrm{V}}$ values of $0.0089 \pm 0.0005$ (\%SD: $6 \%$ ) and $0.0049 \pm 0.0011$ (\%SD: $23 \%$ ), are found, respectively, for the P-MPL and Polly VLDR. As a result, a constant offset, $\Delta\left(=\delta_{\text {Polly }}^{\mathrm{V}}-\delta_{\mathrm{MPL}}^{\mathrm{V}}\right)$, can be assumed between $\delta_{\mathrm{MPL}}^{\mathrm{V}}$ and $\delta_{\text {Polly }}^{\mathrm{V}}$, obtaining $\Delta=$ $-0.0040 \pm 0.0016$. This offset can represent a correction to account for any slight mismatch in the transmitter and detector polarization planes and any impurity of the laser polarization state (Sassen, 2005), as also found in Córdoba-Jabonero et al. (2013) by characterizing the VLDR of a relatively older version (MPL-4) of the polarized MPL systems. Therefore, the P-MPL VLDR must also be corrected by that offset using the expression:

$\delta_{\mathrm{MPL}}^{\mathrm{V} \text { corr }}=\delta_{\mathrm{MPL}}^{\mathrm{V}}+\Delta$,

where $\delta_{\mathrm{MPL}}^{\mathrm{V} \text { corr }}$ is the corrected P-MPL VLDR profile and $\delta_{\mathrm{MPL}}^{\mathrm{V}}$ is the VLDR obtained from Eq. (2). 
Table 2. Mean VLDR values together their standard deviation (SD) (and their relative SD error, in \%) as obtained from the P-MPL and Polly measurements ( $\delta_{\mathrm{MPL}}^{\mathrm{V}}$ and $\delta_{\text {Polly }}^{\mathrm{V}}$ profiles) for aerosol-free height intervals on 29-30 June 2019.

\begin{tabular}{lrr}
\hline Height intervals $(\mathrm{km})$ & $\delta^{\mathrm{V}}$, mean $\pm \mathrm{SD}(\% \mathrm{SD})$ \\
\cline { 2 - 3 } & \multicolumn{2}{c}{ P-MPL } \\
\hline $1.5-2.5$ & $0.0096 \pm 0.0016(16.6)$ & $0.0057 \pm 0.0002(3.4)$ \\
$7.0-8.0$ & $0.0088 \pm 0.0010(10.8)$ & $0.0057 \pm 0.0037(65.9)$ \\
$8.0-9.0$ & $0.0083 \pm 0.0016(19.7)$ & $0.003 \pm 0.016(>100)$ \\
\hline Height averaged & $0.0089 \pm 0.0005(6.0)$ & $0.0049 \pm 0.0011(23.1)$ \\
\hline
\end{tabular}

Regarding the dust layer extended between 3.5 and $5.0 \mathrm{~km}$ height, as expected, a similar $\delta^{\mathrm{V}}$ value to that obtained for the Polly VLDR $\left(\delta_{\text {Polly }}^{\mathrm{V}}=0.11 \pm 0.02\right)$ is estimated for the corrected P-MPL VLDR, i.e. $\delta_{\mathrm{MPL}}^{\mathrm{V} \text { corr }}=0.12 \pm 0.02$, as averaged within that dust layer. The corresponding PLDR to the $\delta^{\mathrm{V}}$ are around 0.3 (as shown in Sect. 3.3), which are typical PLDR values for dust (Burton et al., 2012; Groß et al., 2013).

\subsection{Particle backscatter coefficient (PBC) and particle linear depolarization ratio (PLDR)}

The effect of the OVP correction on the P-MPL RCS is also analysed regarding the retrieval of the KF-derived $\beta_{\mathrm{p}}$ profiles, as obtained by applying both $F_{\mathrm{OVP}}^{\text {original }}$ and $F_{\mathrm{OVP}}^{\text {av }}$ to the RCS. A dust event observed at Leipzig on the night from 29 to 30 June 2019 (the same dust case as in Sect. 3.2) is selected for that purpose. In addition, both PLDR, $\delta_{\mathrm{p}}$ (see Eq. 5), and VLDR, $\delta^{\mathrm{V}}$ (see Eqs. 6 and 7; $\Delta$ offset corrected) are estimated. The OVP-induced effect is illustrated, in particular, using the vertical hourly averaged profiling observed on 29 June 2019 at 20:00-21:00 UT, corresponding to a wellseparated two-layer dust case (dust optical depth of 0.061 ). Figures 5 and 6 show the vertical profiles of $\beta_{\mathrm{p}}$ and $\delta_{\mathrm{p}}$ (and $\delta^{\mathrm{V}}$ ), respectively, depending on the $F_{\mathrm{OVP}}$ applied as retrieved from the P-MPL measurements, together with those derived from the Polly measurements for the selected case.

Both P-MPL and Polly datasets show a dust layer clearly confined between around 3.5 and $5.0 \mathrm{~km}$ height. For comparison, in addition to the AOD-constrained KF solution for the PBC (reference height at $6.0 \mathrm{~km}$ and reference backscatter coefficient of $10^{-7} \mathrm{Mm}^{-1} \mathrm{sr}^{-1}$ ) using $S_{\mathrm{a}}^{\text {eff }}=43 \mathrm{sr}$ (obtained from Polly elastic measurements) (see Fig. 5a), $\beta_{\mathrm{p}}$ is also retrieved using the Raman-derived LR $\left(S_{\mathrm{a}}^{\mathrm{Raman}}=60 \mathrm{sr}\right)$ for that dust layer as obtained from the night-time Polly Raman measurements (data not shown) (see Fig. 5b).

Regarding the dust layer, relatively small differences are found between Polly and P-MPL $\beta_{\mathrm{p}}$ profiles (see Fig. 5), at least within error uncertainties. In order to assess the differences between both datasets, the layer-averaged PBC, $\overline{\beta_{\mathrm{p}}}$ $\left(\mathrm{Mm}^{-1} \mathrm{sr}^{-1}\right)$, and the integrated backscatter, $B\left(\mathrm{sr}^{-1}\right)$, for this $3.5-5.0 \mathrm{~km}$ dust layer were calculated to be used as a proxy of the degree of agreement. Derived $\overline{\beta_{\mathrm{p}}}$ and $B$ values (a)
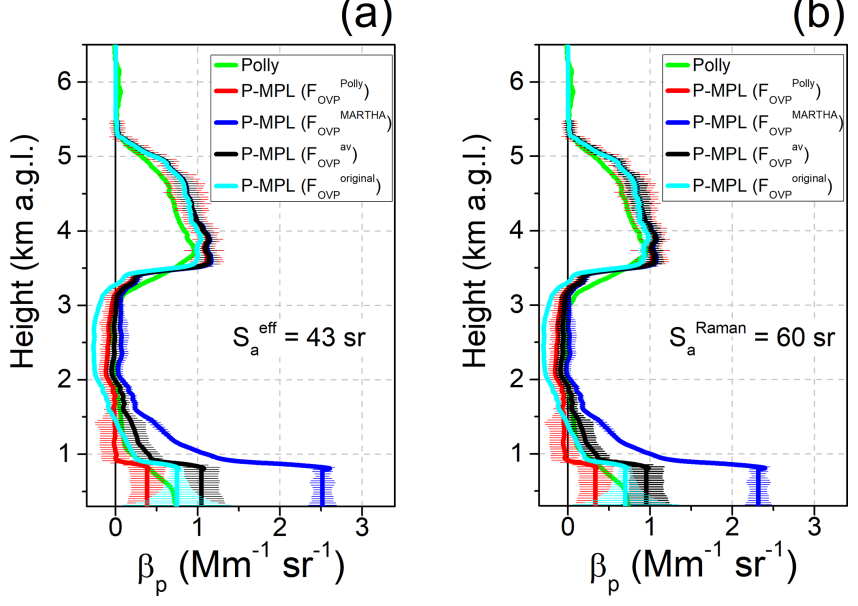

Figure 5. Dust case observed on 29 June 2019 at 20:00-21:00 UT over Leipzig. Vertical particle backscatter coefficient (PBC), $\beta_{\mathrm{p}}$, as retrieved by using the particular OVP function applied to the P-MPL RCS: $F_{\text {OVP }}$ with respect to Polly (red) and MARTHA (blue) data

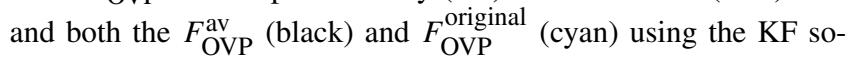
lution with (a) the elastic AOD-constrained LR ( $\left.S_{\mathrm{a}}^{\text {eff }}=43 \mathrm{sr}\right)$, and (b) the Raman-retrieved LR $\left(S_{\mathrm{a}}^{\text {Raman }}=60 \mathrm{sr}\right)$ for the dust layer. Corresponding Polly-retrieved $\beta_{\mathrm{p}}$ profiles are also included (green lines).

depending on $F_{\text {OVP }}$ for both the KF solutions (using either $S_{\mathrm{a}}^{\text {eff }}$ or $S_{\mathrm{a}}^{\text {Raman }}$ ) are shown in Table 3. In general, $\overline{\beta_{\mathrm{p}}}$ and $B$ are higher for P-MPL with respect to Polly retrievals. Concerning the KF solutions for P-MPL profiles, a better agreement is achieved when the $S_{\mathrm{a}}^{\text {Raman }}$ of 60 sr is applied (no AOD constraint), i.e. lower differences for $\overline{\beta_{\mathrm{p}}}$ and $B$ are found with respect to Polly-retrieved values.

Nevertheless, the KF retrieval is mostly affected at nearfield ranges (up to $3 \mathrm{~km}$ height) (see Fig. 5), as expected, since the OVP correction is rather relevant at those ranges. Negative $\beta_{\mathrm{p}}$ values are predominantly found for the scenarios when the RCS is OVP-corrected by $F_{\mathrm{OVP}}^{\text {Polly }}$ and $F_{\mathrm{OVP}}^{\text {original }}$, and are more pronounced when the $S_{\mathrm{a}}^{\mathrm{Raman}}$ is applied, since the LR to be applied in this height interval must be closer to the elastic $S_{\mathrm{a}}^{\text {eff }}$ of $43 \mathrm{sr}$. The best fitting seems to be achieved using $F_{\mathrm{OVP}}^{\mathrm{MARTA}}$ and $F_{\mathrm{OVP}}^{\mathrm{av}}$. Among those, however, the re- 
Table 3. Dust layer-averaged PBC, $\overline{\beta_{\mathrm{p}}}\left(\mathrm{Mm}^{-1} \mathrm{sr}^{-1}\right)$, and PLDR, $\overline{\delta_{\mathrm{p}}}$, and the integrated backscatter, $B\left(10^{-3} \mathrm{sr}^{-1}\right)$, values, as obtained from P-MPL $\beta_{\mathrm{p}}$ and $\delta_{\mathrm{p}}$ profiles on 29 June 2019 at 20:00-21:00 UT depending on the $F_{\text {OVP }}$ applied for both KF solutions (using $S_{\mathrm{a}}^{\text {eff }}$ and $S_{\mathrm{a}}^{\text {Raman }}$ ). Corresponding Polly values are also included.

\begin{tabular}{|c|c|c|c|c|c|c|c|c|c|}
\hline \multicolumn{7}{|c|}{ P-MPL } & \multirow{2}{*}{\multicolumn{3}{|c|}{$\begin{array}{c}\text { Polly } \\
S_{\mathrm{a}}^{\text {eff }}=43 \mathrm{sr}\end{array}$}} \\
\hline$F_{\mathrm{OVP}}$ & \multicolumn{3}{|c|}{$S_{\mathrm{a}}^{\mathrm{eff}}=43 \mathrm{sr}$} & \multicolumn{3}{|c|}{$S_{\mathrm{a}}^{\text {Raman }}=60 \mathrm{sr}$} & & & \\
\hline & $\overline{\beta_{\mathrm{p}}}$ & $B$ & $\overline{\delta_{\mathrm{p}}}$ & $\overline{\beta_{\mathrm{p}}}$ & $B$ & $\overline{\delta_{\mathrm{p}}}$ & $\overline{\beta_{\mathrm{p}}}$ & $B$ & $\overline{\delta_{\mathrm{p}}}$ \\
\hline$F_{\mathrm{OVP}}^{\mathrm{av}}$ & $0.93 \pm 0.17$ & $1.41 \pm 0.16$ & $0.32 \pm 0.01$ & $0.89 \pm 0.15$ & $1.35 \pm 0.16$ & $0.33 \pm 0.01$ & \multirow{4}{*}{$0.72 \pm 0.16$} & \multirow{4}{*}{1.08} & \multirow{4}{*}{$0.33 \pm 0.01$} \\
\hline$F_{\text {OVP }}^{\text {Polly }}$ & $0.92 \pm 0.16$ & $1.40 \pm 0.27$ & $0.32 \pm 0.01$ & $0.88 \pm 0.14$ & $1.33 \pm 0.27$ & $0.33 \pm 0.01$ & & & \\
\hline$F_{\mathrm{OVP}}^{\mathrm{MARTHA}}$ & $0.94 \pm 0.17$ & $1.43 \pm 0.10$ & $0.32 \pm 0.01$ & $0.90 \pm 0.15$ & $1.36 \pm 0.10$ & $0.32 \pm 0.01$ & & & \\
\hline$F_{\mathrm{OVP}}^{\text {original }}$ & $0.87 \pm 0.14$ & $1.32 \pm 0.05$ & $0.33 \pm 0.01$ & $0.83 \pm 0.12$ & $1.26 \pm 0.08$ & $0.34 \pm 0.02$ & & & \\
\hline
\end{tabular}

(a)

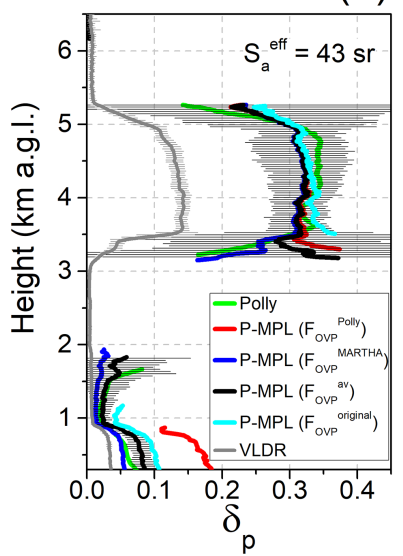

Figure 6. The same as Fig. 5, but for the vertical particle linear depolarization ratio (PLDR), $\delta_{\mathrm{p}}$, as retrieved from each $\beta_{\mathrm{p}}\left[F_{\mathrm{OVP}}\right]$ as shown in Fig. 5 and the VLDR, $\delta^{\mathrm{V}}$ (grey line). The corresponding Polly-retrieved $\delta_{\mathrm{p}}$ profile is also included (green line). For clarity, error bars are only marked for $\delta_{\mathrm{p}}\left[F_{\mathrm{OVP}}^{\mathrm{av}}\right]$ (black) and $\delta_{\mathrm{p}}^{\text {Polly }}$ (green).

sults show that $\beta_{\mathrm{p}}$ profiles are in a better agreement using $F_{\mathrm{OVP}}^{\mathrm{av}}$ as compared to the Polly-derived $\beta_{\mathrm{p}}$ at ranges from around $1 \mathrm{~km}$ down (see Fig. 5). Relative $\beta_{\mathrm{p}}\left[F_{\mathrm{OVP}}^{\mathrm{av}}\right]$ errors of $10 \%-20 \%$ are obtained.

By examining the PLDR profiles, the dust signature is also clearly marked between around 3.5 and $5.0 \mathrm{~km}$ height, i.e. typical $\delta_{\mathrm{p}}$ values for dust of around 0.3 are found (see Table 3 ), indicating a predominance of coarse particles. No differences are found between Polly and P-MPL PLDR profiles for that layer (see Fig. 6), with mean $\delta_{\mathrm{p}}$ values of $0.33 \pm 0.01$ (Polly) and 0.32-0.34 \pm 0.02 (P-MPL, depending on the $F_{\text {OVP }}$ applied and the LR used) (see Table 3 ).

\section{Conclusions}

A comprehensive 2-month field intercomparison campaign was performed in summer 2019 to characterize the performance of a polarized micro-pulse lidar (P-MPL) system and to check the quality of the retrieved aerosol products. Atmospheric observations of the P-MPL system have been examined against those from two reference EARLINET lidars (Polly and MARTHA), which are operative at the Leipzig site Germany, $51.4^{\circ} \mathrm{N}, 12.4^{\circ} \mathrm{E} ; 125 \mathrm{~m}$ a.s.1.) and managed by TROPOS. In particular, an experimental assessment in terms of the overlap (OVP) correction and its impact on the retrieval of the aerosol optical properties has been achieved. Furthermore, the volume linear depolarization ratio (VLDR) has also been cross-checked and corrections applied, allowing an accurate retrieval. The aim of this work was focused on determining the lidar-specific true OVP function and on investigating the accuracy of both the retrieved particle backscatter coefficient (PBC) and particle linear depolarization ratio (PLDR) profiles.

It has been highlighted that the OVP function as delivered by the P-MPL manufacturer cannot be used long. The reasons are manifold, but a suitable estimation of the OVP function should be recommended for the MPL system. The experimental procedure to determine the OVP function for the P-MPL system has been described on the basis of the comparison to reference lidars. The optimal OVP function for correcting the P-MPL measurements has been obtained, together with its uncertainties, under clean observational conditions from simultaneous P-MPL and Polly/MARTHA observations and compared with the original one as provided by the manufacturer. In addition, depending on the OVP function applied, the OVP correction-induced effects on the retrieval of both the PBC and PLDR for the P-MPL system have been analysed for two KF solutions using either the elastic (AOD-constrained) or the Raman-provided lidar ratios in comparison with the PBC and PLDR retrievals as obtained from simultaneous Polly observations. A dust case observed at Leipzig is analysed for that purpose. Additionally, 
despite the fact that VLDR is OVP-unaffected, it has also been examined in comparison with the Polly VLDR regarding its effect in the PLDR determination. A suitable VLDR profile was obtained and only needed to be corrected by a small offset value, which has also been estimated. Once PMPL measurements were optimally OVP-corrected and the VLDR adjusted, both the PBC and PLDR profiles were accurately derived using the KF solution.

Overall, as a systematic requirement for lidar systems, an adequate OVP function determination, and a VLDR testing analysis needs to be performed on a regular basis in order to correct the P-MPL measurements and, hence, to derive suitable aerosol products (backscatter, depolarization, extinction). The procedure described in this study could be useful in similar P-MPL systems that cannot regularly apply the established MPLNET calibrations. Moreover, such effort should be addressed with the purpose of combining all existing networks in Europe (EARLINET), Asia (AD-NET), Latin America (LALINET), and also MPLNET within the future vision of GAW (Global Atmospheric Watch) Aerosol LIdar Observations Network (GALION). 


\section{Appendix A}

The experimental overlap (OVP) function, $F_{\mathrm{OVP}}^{\mathrm{ref}}(z)$, is obtained from the expression

$$
F_{\mathrm{OVP}}^{\mathrm{ref}}(z)=P^{\mathrm{MPL}}(z) / P^{\mathrm{ref}}(z),
$$

where $P^{\mathrm{MPL}}(z)$ are the P-MPL RCS profiles, which are compared against the reference lidar measurements, $P^{\text {ref }}(z)$ (ref denotes either Polly or MARTHA), using the experimental approach described in this work.

The error associated with the determination of the OVP function, $\Delta F_{\mathrm{OVP}}$, is obtained from error propagation calculations of the Eq. (A1). In this sense, it can be expressed as ( $z$ dependence is hereafter omitted for simplicity)

$\Delta F_{\mathrm{OVP}}^{\mathrm{ref}}=F_{\mathrm{OVP}}^{\mathrm{ref}} \times\left[\frac{\Delta P^{\mathrm{MPL}}}{P^{\mathrm{MPL}}}+\frac{\Delta P^{\mathrm{ref}}}{P^{\mathrm{ref}}}\right]$,

where $\Delta P^{\mathrm{MPL}}$ and $\Delta P^{\mathrm{ref}}$ are, respectively, the errors related to $P^{\mathrm{MPL}}$ and $P^{\mathrm{ref}}$.

$\Delta P^{\mathrm{MPL}}$ can be estimated as being composed of two error contributions: one associated with instrumental corrections (energy fluctuations, instrumental calibrations, solar background, etc.), $\varepsilon^{\mathrm{MPL}}$, as described in Welton and Campbell (2002), and another one reflecting the atmospheric variability within the time averaging performed by the $P^{\mathrm{MPL}}$ profiles, which is expressed by the standard deviation, $\mathrm{SD}^{\mathrm{MPL}}$; hence, it can be obtained from the expression

$$
\Delta P^{\mathrm{MPL}}=\sqrt{\left(\varepsilon^{\mathrm{MPL}}\right)^{2}+\left(\mathrm{SD}^{\mathrm{MPL}}\right)^{2}} .
$$

Errors associated with the reference lidar measurements, $\Delta P^{\text {ref }}$ (ref is for either Polly or MARTHA), are represented by the standard deviation, as obtained from the corresponding time averaging of $P^{\text {ref }}$ profiles.
In this work, the averaged function between $F_{\text {OVP }}^{\text {Polly }}$ and $F_{\mathrm{OVP}}^{\mathrm{MARTHA}}$ is also calculated, i.e.

$F_{\mathrm{OVP}}^{\mathrm{av}}=\frac{F_{\mathrm{OVP}}^{\mathrm{Polly}}+F_{\mathrm{OVP}}^{\mathrm{MARTHA}}}{2}$,

where the error related to this function, $\Delta F_{\mathrm{OVP}}^{\mathrm{av}}$, is estimated as

$\Delta F_{\mathrm{OVP}}^{\mathrm{av}}=\sqrt{\left(\frac{\Delta F_{\mathrm{OVP}}^{\mathrm{Polly}}}{2}\right)^{2}+\left(\frac{\Delta F_{\mathrm{OVP}}^{\mathrm{MARTHA}}}{2}\right)^{2}}$,

where $\Delta F_{\mathrm{OVP}}^{\mathrm{ref}}$ (ref denotes either Polly or MARTHA) is the error obtained from Eq. (A2). 
Data availability. All data generated and analysed for this study are available from the authors upon reasonable request.

Author contributions. CCJ and AA designed the study and wrote the original draft of the manuscript. CCJ, AA, CJ, and HB provided data. CCJ and CJ performed data analysis with contributions from AA, HB, MALC, and RE. All authors reviewed and edited the final version of the manuscript. All authors agreed on the final version of the manuscript.

Competing interests. The authors declare that they have no conflict of interest.

Disclaimer. Publisher's note: Copernicus Publications remains neutral with regard to jurisdictional claims in published maps and institutional affiliations.

Acknowledgements. This work was supported by the Spanish Ministry of Science, Innovation and Universities (MCIU) under grants PRX18/00137 (Programa "Salvador de Madariaga") and CGL201790884-REDT (ACTRIS-Spain), the Spanish Ministry of Science and Innovation (MICINN) (grant PID2019-104205GB-C21), and the H2020 programme from the European Union (ACTRIS, GA n. 871115). María-Ángeles López-Cayuela is supported by the INTA predoctoral contract programme. We thank MPLNET for its support even though this study was not part of MPLNET activities. The MPLNET project is funded by the NASA Radiation Sciences Program and Earth Observing System.

Financial support. This research has been supported by the Ministerio de Ciencia, Innovación y Universidades (grant nos. PRX18/00137 and CGL2017-90884-REDT), the Ministerio de Ciencia e Innovación (grant no. PID2019-104205GB-C21), and the H2020 European Research Council (grant no. 871115).

Review statement. This paper was edited by Daniel Perez-Ramirez and reviewed by three anonymous referees.

\section{References}

Althausen, D., Engelmann, R., Baars, H., Heese, B., Ansmann, A., Müller, D., and Komppula, M.: Portable Raman Lidar PollyXT for Automated Profiling of Aerosol Backscatter, Extinction, and Depolarization, J. Atmos. Ocean. Tech., 26, 2366-2378, https://doi.org/10.1175/2009JTECHA1304.1, 2009.

Amiridis, V., Marinou, E., Tsekeri, A., Wandinger, U., Schwarz, A., Giannakaki, E., Mamouri, R., Kokkalis, P., Binietoglou, I., Solomos, S., Herekakis, T., Kazadzis, S., Gerasopoulos, E., Proestakis, E., Kottas, M., Balis, D., Papayannis, A., Kontoes, C., Kourtidis, K., Papagiannopoulos, N., Mona, L., Pappalardo, G., Le Rille, O., and Ansmann, A.: LIVAS: a 3-D multi-wavelength aerosol/cloud database based on CALIPSO and EARLINET, Atmos. Chem. Phys., 15, 7127-7153, https://doi.org/10.5194/acp15-7127-2015, 2015.

Ansmann, A., Tesche, M., Seifert, P., Groß, S., Freudenthaler, V., Apituley, A., Wilson, K. M., Serikov, I., Linné, H., Heinold, B., Hiebsch, A., Schnell, F., Schmidt, J., Mattis, I., Wandinger, U., and Wiegner, M.: Ash and fine-mode particle mass profiles from EARLINET-AERONET observations over central Europe after the eruptions of the Eyjafjallajökull volcano in 2010, J. Geophys. Res., 116, D00U02, https://doi.org/10.1029/2010JD015567, 2011.

Baars, H., Kanitz, T., Engelmann, R., Althausen, D., Heese, B., Komppula, M., Preißler, J., Tesche, M., Ansmann, A., Wandinger, U., Lim, J.-H., Ahn, J. Y., Stachlewska, I. S., Amiridis, V., Marinou, E., Seifert, P., Hofer, J., Skupin, A., Schneider, F., Bohlmann, S., Foth, A., Bley, S., Pfüller, A., Giannakaki, E., Lihavainen, H., Viisanen, Y., Hooda, R. K., Pereira, S. N., Bortoli, D., Wagner, F., Mattis, I., Janicka, L., Markowicz, K. M., Achtert, P., Artaxo, P., Pauliquevis, T., Souza, R. A. F., Sharma, V. P., van Zyl, P. G., Beukes, J. P., Sun, J., Rohwer, E. G., Deng, R., Mamouri, R.-E., and Zamorano, F.: An overview of the first decade of PollyNET: an emerging network of automated Raman-polarization lidars for continuous aerosol profiling, Atmos. Chem. Phys., 16, 5111-5137, https://doi.org/10.5194/acp16-5111-2016, 2016.

Baars, H., Ansmann, A., Ohneiser, K., Haarig, M., Engelmann, R., Althausen, D., Hanssen, I., Gausa, M., Pietruczuk, A., Szkop, A., Stachlewska, I. S., Wang, D., Reichardt, J., Skupin, A., Mattis, I., Trickl, T., Vogelmann, H., Navas-Guzmán, F., Haefele, A., Acheson, K., Ruth, A. A., Tatarov, B., Müller, D., Hu, Q., Podvin, T., Goloub, P., Veselovskii, I., Pietras, C., Haeffelin, M., Fréville, P., Sicard, M., Comerón, A., Fernández García, A. J., Molero Menéndez, F., Córdoba-Jabonero, C., Guerrero-Rascado, J. L., Alados-Arboledas, L., Bortoli, D., Costa, M. J., Dionisi, D., Liberti, G. L., Wang, X., Sannino, A., Papagiannopoulos, N., Boselli, A., Mona, L., D’Amico, G., Romano, S., Perrone, M. R., Belegante, L., Nicolae, D., Grigorov, I., Gialitaki, A., Amiridis, V., Soupiona, O., Papayannis, A., Mamouri, R.-E., Nisantzi, A., Heese, B., Hofer, J., Schechner, Y. Y., Wandinger, U., and Pappalardo, G.: The unprecedented 2017-2018 stratospheric smoke event: decay phase and aerosol properties observed with the EARLINET, Atmos. Chem. Phys., 19, 1518315198, https://doi.org/10.5194/acp-19-15183-2019, 2019.

Barbosa, H. M. J., Lopes, F. J. S., Silva, A., Nisperuza, D., Barja, B., Ristori, P., Gouveia, D. A., Jimenez, C., Montilla, E., Mariano, G. L., Landulfo, E., Bastidas, A., and Quel, E. J.: The first ALINE measurements and intercomparison exercise on lidar inversion algorithms, Óptica Pura Y Aplicada, 47, 99-108, https://doi.org/10.7149/OPA.47.2.99, 2014.

Behrendt, A. and Nakamura, T.: Calculation of the calibration constant of polarization lidar and its dependency on atmospheric temperature, Opt. Express, 10, 805-817, https://doi.org/10.1364/OE.10.000805, 2002.

Belegante, L., Bravo-Aranda, J. A., Freudenthaler, V., Nicolae, D., Nemuc, A., Ene, D., Alados-Arboledas, L., Amodeo, A., Pappalardo, G., D’Amico, G., Amato, F., Engelmann, R., Baars, H., Wandinger, U., Papayannis, A., Kokkalis, P., and Pereira, S. N.: Experimental techniques for the calibration of lidar depolariza- 
tion channels in EARLINET, Atmos. Meas. Tech., 11, 11191141, https://doi.org/10.5194/amt-11-1119-2018, 2018.

Berkoff, T. A., Welton, E. J., Campbell, J.R., Scott, V.S., and Spinhirne, J. D.: Investigation of Overlap Correction Techniques for the Micro-Pulse Lidar NETwork (MPLNET), 2003 IEEE International Geoscience and Remote Sensing Symposium (2003 IGARSS). Proceedings (IEEE Cat. No. 03CH37477), Toulouse, France, 21-25 July 2003, 4395-4397, https://doi.org/10.1109/IGARSS.2003.1295527, 2003.

Böckmann, C., Wandinger, U., Ansmann, A., Bösenberg, J., Amiridis, V., Boselli, A., Delaval, A., Tomasi, F. D., Frioud, M., Grigorov, I. V., Hågård, A., Horvat, M., Iarlori, M., Komguem, L., Kreipl, S., Larchevêque, G., Matthias, V., Papayannis, A., Pappalardo, G., Rocadenbosch, F., Rodrigues, J. A., Schneider, J., Shcherbakov, V., and Wiegner, M.: Aerosol lidar intercomparison in the framework of the EARLINET project. 2. Aerosol backscatter algorithms, Appl. Optics, 43, 977-989, https://doi.org/10.1364/AO.43.000977, 2004.

Bohlmann, S., Shang, X., Giannakaki, E., Filioglou, M., Saarto, A., Romakkaniemi, S., and Komppula, M.: Detection and characterization of birch pollen in the atmosphere using a multiwavelength Raman polarization lidar and Hirst-type pollen sampler in Finland, Atmos. Chem. Phys., 19, 14559-14569, https://doi.org/10.5194/acp-19-14559-2019, 2019.

Burton, S. P., Ferrare, R. A., Hostetler, C. A., Hair, J. W., Rogers, R. R., Obland, M. D., Butler, C. F., Cook, A. L., Harper, D. B., and Froyd, K. D.: Aerosol classification using airborne High Spectral Resolution Lidar measurements - methodology and examples, Atmos. Meas. Tech., 5, 73-98, https://doi.org/10.5194/amt-5-732012, 2012.

Burton, S. P., Vaughan, M. A., Ferrare, R. A., and Hostetler, C. A.: Separating mixtures of aerosol types in airborne High Spectral Resolution Lidar data, Atmos. Meas. Tech., 7, 419-436, https://doi.org/10.5194/amt-7-419-2014, 2014.

Campbell, J. R. and Sassen, K.: Polar stratospheric clouds at the South Pole from 5 years of continuous lidar data: Macrophysical, optical, and thermodynamic properties, J. Geophys. Res., 113, D20204, https://doi.org/10.1029/2007JD009680, 2008.

Campbell, J. R., Hlavka, D. L., Welton, E. J., Flynn, C. J., Turner, D. D., Spinhirne, J. D., Scott, V. S., and Hwang, I. H.: Full-Time, Eye-Safe Cloud and Aerosol Lidar Observation at Atmospheric Radiation Measurement Program Sites: Instruments and Data Processing, J. Atmos. Ocean. Tech., 19, 431-442, https://doi.org/10.1175/15200426(2002)019<0431:FTESCA>2.0.CO;2, 2002.

Campbell, J. R., Lolli, S., Lewis, J. R., Gu, Y., and Welton, E. J.: Daytime Cirrus Cloud Top-of-Atmosphere Radiative Forcing Properties at a Midlatitude Site and their Global Consequence, J. Appl. Meteorol. Clim., 5, 1667-1679, https://doi.org/10.1175/JAMC-D-15-0217.1, 2016.

Campbell, J. R., Dolinar, E. K., Lolli, S., Fochesatto, G. J., Gu, Y., Lewis, J. R., Marquis, J. W., McHardy, T. M., Ryglicki, R. R., and Welton, E. J.: Cirrus cloud top-of-the-atmosphere net daytime forcing in the Alaskan subarctic from ground-based MPLNET monitoring, J. Appl. Meteorol. Clim., 60, 51-63, https://doi.org/10.1175/JAMC-D-20-0077.1, 2021.

Córdoba-Jabonero, C., Guerrero-Rascado, J. L., Toledo, D., Parrondo, M., Yela, M., Gil, M., and Ochoa, H. A.: Depolarization ratio of polar stratospheric clouds in coastal Antarctica: compari- son analysis between ground-based Micro Pulse Lidar and spaceborne CALIOP observations, Atmos. Meas. Tech., 6, 703-717, https://doi.org/10.5194/amt-6-703-2013, 2013.

Córdoba-Jabonero, C., Andrey-Andrés, J., Gómez, L., Adame, J. A., Sorribas, M., Navarro-Comas, M., Puentedura, O., Cuevas, E., and Gil-Ojeda, M.: Vertical mass impact and features of Saharan dust intrusions derived from ground-based remote sensing in synergy with airborne in-situ measurements, Atmos. Environ., 142, 420-429, https://doi.org/10.1016/j.atmosenv.2016.08.003, 2016.

Córdoba-Jabonero, C., Lopes, F. J. S., Landulfo, E., Cuevas, E., Ochoa, H., and Gil-Ojeda, M.: Diversity on subtropical and polar cirrus clouds properties as derived from both ground-based lidars and CALIPSO/CALIOP measurements, Atmos. Res., 183, 151-165, https://doi.org/10.1016/j.atmosres.2016.08.015, 2017.

Córdoba-Jabonero, C., Sicard, M., Ansmann, A., del Águila, A., and Baars, H.: Separation of the optical and mass features of particle components in different aerosol mixtures by using POLIPHON retrievals in synergy with continuous polarized Micro-Pulse Lidar (P-MPL) measurements, Atmos. Meas. Tech., 11, 4775-4795, https://doi.org/10.5194/amt-114775-2018, 2018.

Córdoba-Jabonero, C., Sicard, M., del Águila, A., Jiménez, M., and Zorzano, M.-P.: Performance of a dust model to predict the vertical mass concentration of an extreme Saharan dust event in the Iberian Peninsula: Comparison with continuous, elastic, polarization-sensitive lidars, Atmos. Environ., 214, 116828, https://doi.org/10.1016/j.atmosenv.2019.116828, 2019.

Córdoba-Jabonero, C., Gómez-Martín, L., del Águila, A., Vilaplana, J. M., López-Cayuela, M. A., and Zorzano, M.P.: Cirrus-induced shortwave radiative effects depending on their optical and physical properties: Case studies using simulations and measurements, Atmos. Res., 246, 105095, https://doi.org/10.1016/j.atmosres.2020.105095, 2020.

Córdoba-Jabonero, C., Sicard, M., López-Cayuela, M.-Á., Ansmann, A., Comerón, A., Zorzano, M.-P., Rodríguez-Gómez, A., and Muñoz-Porcar, C.: Aerosol radiative impact during the summer 2019 heatwave produced partly by an intercontinental Saharan dust outbreak - Part 1: Short-wave dust direct radiative effect, Atmos. Chem. Phys., 21, 6455-6479, https://doi.org/10.5194/acp-21-6455-2021, 2021.

Engelmann, R., Kanitz, T., Baars, H., Heese, B., Althausen, D., Skupin, A., Wandinger, U., Komppula, M., Stachlewska, I. S., Amiridis, V., Marinou, E., Mattis, I., Linné, H., and Ansmann, A.: The automated multiwavelength Raman polarization and water-vapor lidar Polly XT: the neXT generation, Atmos. Meas. Tech., 9, 1767-1784, https://doi.org/10.5194/amt-9-1767-2016, 2016.

Fernald, F. G.: Analysis of atmospheric lidar observations: some comments, Appl. Optics, 23, 652-653, https://doi.org/10.1364/AO.23.000652, 1984.

Flynn, C. J., Mendoza, A., Zheng, Y., and Mathur, S.: Novel polarization-sensitive micropulse lidar measurement technique, Opt. Express, 15, 2785-2790, https://doi.org/10.1364/OE.15.002785, 2007.

Freudenthaler, V.: The telecover test: A quality assurance tool for the optical part of a lidar system, in: 24th International Laser Radar Conference, 23-27 June 2008, Boulder, Colorado, https://doi.org/10.5282/ubm/epub.12958, 2008. 
Freudenthaler, V.: About the effects of polarising optics on lidar signals and the $\Delta 90$ calibration, Atmos. Meas. Tech., 9, 41814255, https://doi.org/10.5194/amt-9-4181-2016, 2016.

Gimmestad, G. G.: Reexamination of depolarization in lidar measurements, Appl. Optics, 47, 3795-3802, 2008.

Granados-Muñoz, M. J., Bravo-Aranda, J. A., Baumgardner, D., Guerrero-Rascado, J. L., Pérez-Ramírez, D., Navas-Guzmán, F., Veselovskii, I., Lyamani, H., Valenzuela, A., Olmo, F. J., Titos, G., Andrey, J., Chaikovsky, A., Dubovik, O., Gil-Ojeda, M., and Alados-Arboledas, L.: A comparative study of aerosol microphysical properties retrieved from ground-based remote sensing and aircraft in situ measurements during a Saharan dust event, Atmos. Meas. Tech., 9, 1113-1133, https://doi.org/10.5194/amt9-1113-2016, 2016.

Groß, S., Esselborn, M., Weinzierl, B., Wirth, M., Fix, A., and Petzold, A.: Aerosol classification by airborne high spectral resolution lidar observations, Atmos. Chem. Phys., 13, 2487-2505, https://doi.org/10.5194/acp-13-2487-2013, 2013.

Guerrero-Rascado, J. L., Costa, M. J, Bortoli, D., Silva, A. M., Lyamani, H., and Alados-Arboledas L: Infrared lidar overlap function: an experimental determination, Opt. Express, 18, 2035020369, 2010.

Jimenez, C., Ansmann, A., Donovan, D., Engelmann, R., Schmidt, J., and Wandinger, U.: Comparison between two lidar methods to retrieve microphysical properties of liquid-water clouds, EPJ Web Conf., 176, 01032, https://doi.org/10.1051/epjconf/201817601032, 2018.

Jimenez, C., Ansmann, A., Engelmann, R., Haarig, M., Schmidt, J., and Wandinger, U.: Polarization lidar: an extended threesignal calibration approach, Atmos. Meas. Tech., 12, 1077-1093, https://doi.org/10.5194/amt-12-1077-2019, 2019.

Klett, J. D.: Lidar inversion with variable backscatter/extinction ratios, Appl. Optics, 24, 1638-1643, https://doi.org/10.1364/AO.24.001638, 1985.

Lewis, J. R., Welton, E. J., Molod, A. M., and Joseph, E.: Improved boundary layer depth retrievals from MPLNET, J. Geophys. Res.-Atmos., 118, 9870-9879, https://doi.org/10.1002/jgrd.50570, 2013.

Lewis, J. R., Campbell, J. R., Welton, E. J., Stewart, S. A., and Haftings, P. C.: Overview of MPLNET Version 3 Cloud Detection, J. Atmos. Ocean. Tech., 33, 2113-2134, https://doi.org/10.1175/JTECH-D-15-0190.1, 2016.

Lewis, J. R., Campbell, J. R., Stewart, S. A., Tan, I., Welton, E. J., and Lolli, S.: Determining cloud thermodynamic phase from the polarized Micro Pulse Lidar, Atmos. Meas. Tech., 13, 69016913, https://doi.org/10.5194/amt-13-6901-2020, 2020.

Lolli, S., Campbell, J. R., Lewis, J. R., Gu, Y., Marquis, J. W., Chew, B. N., Liew, S., Salinas, S. V., and Welton, E. J.: Daytime Top-of-the-Atmosphere Cirrus Cloud Radiative Forcing Properties at Singapore, J. Appl. Meteorol. Clim., 56, 1249-1257, https://doi.org/10.1175/JAMC-D-16-0262.1, 2017.

Lolli, S., D’Adderio, L. P., Campbell, J. R., Sicard, M., Welton, E. J., Binci, A., Rea, A., Tokay, A., Comerón, A., Barragan, R., Baldasano, J. M., Gonzalez, S., Bech, J., Afflitto, N., Lewis, J. R., and Madonna, F.: Vertically Resolved Precipitation Intensity Retrieved through a Synergy between the Ground-Based NASA MPLNET Lidar Network Measurements, Surface Disdrometer Datasets and an Analytical Model Solution, Remote Sens., 10, 1102, https://doi.org/10.3390/rs10071102, 2018.
Lolli, S., Vivone, G., Lewis, J. R., Sicard, M., Welton, E. J., Campbell, J. R., Comerón, A., D’Adderio, 1. P., Tokay, A., Giunta, A., and Pappalardo, G.: Overview of the New Version 3 NASA Micro-Pulse Lidar Network (MPLNET) Automatic Precipitation Detection Algorithm, Remote Sens., 12, 71, https://doi.org/10.3390/rs12010071, 2020.

Mamouri, R.-E. and Ansmann, A.: Potential of polarization lidar to provide profiles of $\mathrm{CCN}$ - and INP-relevant aerosol parameters, Atmos. Chem. Phys., 16, 5905-5931, https://doi.org/10.5194/acp-16-5905-2016, 2016.

Mamouri, R.-E. and Ansmann, A.: Potential of polarization/Raman lidar to separate fine dust, coarse dust, maritime, and anthropogenic aerosol profiles, Atmos. Meas. Tech., 10, 3403-3427, https://doi.org/10.5194/amt-10-3403-2017, 2017.

Marenco, F., Santacesaria, V., Bais, A. F., Balis, D., di Sarra, A., Papayannis, A. and Zerefos, C.: Optical properties of tropospheric aerosols determined by lidar and spectrophotometric measurements (Photochemical Activity and Solar Ultraviolet Radiation campaign), Appl. Optics, 36, 6875-6886, 1997.

Mattis, I., Müller, D., Ansmann, A., Wandinger, U., Preißler, J., Seifert, P. and Tesche, M.: Ten years of multiwavelength Raman lidar observations of free-tropospheric aerosol layers over central Europe: Geometrical properties and annual cycle, J. Geophys. Res., 113, D20202, https://doi.org/10.1029/2007JD009636, 2008.

Mishchenko, M. I. and Hovenier, J. W.: Depolarization of light backscattered by randomly oriented nonspherical particles, Opt. Lett., 20, 1356-1358, 1995.

Pappalardo, G., Amodeo, A., Pandolfi, M., Wandinger, U., Ansmann, A., Bösenberg, J., Matthias, V., Amiridis, V., Tomasi, F. D., Frioud, M., Iarlori, M., Komguem, L., Papayannis, A., Rocadenbosch, F., and Wang, X.: Aerosol lidar intercomparison in the framework of the EARLINET project. 3. Raman lidar algorithm for aerosol extinction, backscatter, and lidar ratio, Appl. Optics, 43, 5370-5385, https://doi.org/10.1364/AO.43.005370, 2004.

Pappalardo, G., Mona, L., D’Amico, G., Wandinger, U., Adam, M., Amodeo, A., Ansmann, A., Apituley, A., Alados Arboledas, L., Balis, D., Boselli, A., Bravo-Aranda, J. A., Chaikovsky, A., Comeron, A., Cuesta, J., De Tomasi, F., Freudenthaler, V., Gausa, M., Giannakaki, E., Giehl, H., Giunta, A., Grigorov, I., Groß, S., Haeffelin, M., Hiebsch, A., Iarlori, M., Lange, D., Linné, H., Madonna, F., Mattis, I., Mamouri, R.-E., McAuliffe, M. A. P., Mitev, V., Molero, F., Navas-Guzman, F., Nicolae, D., Papayannis, A., Perrone, M. R., Pietras, C., Pietruczuk, A., Pisani, G., Preißler, J., Pujadas, M., Rizi, V., Ruth, A. A., Schmidt, J., Schnell, F., Seifert, P., Serikov, I., Sicard, M., Simeonov, V., Spinelli, N., Stebel, K., Tesche, M., Trickl, T., Wang, X., Wagner, F., Wiegner, M., and Wilson, K. M.: Four-dimensional distribution of the 2010 Eyjafjallajökull volcanic cloud over Europe observed by EARLINET, Atmos. Chem. Phys., 13, 4429-4450, https://doi.org/10.5194/acp-13-4429-2013, 2013.

Pappalardo, G., Amodeo, A., Apituley, A., Comeron, A., Freudenthaler, V., Linné, H., Ansmann, A., Bösenberg, J., D’Amico, G., Mattis, I., Mona, L., Wandinger, U., Amiridis, V., AladosArboledas, L., Nicolae, D., and Wiegner, M.: EARLINET: towards an advanced sustainable European aerosol lidar network, Atmos. Meas. Tech., 7, 2389-2409, https://doi.org/10.5194/amt7-2389-2014, 2014. 
Sassen, K.: Lidar: range-resolved optical remote sensing of the atmosphere, Chap. 2 Polarization in lidar, in: Springer Series in Optical Sciences, Springer Science+Business Media Inc., Springer-Verlag, New York, 102, https://doi.org/10.1007/0-38725101-4_2, 2005.

Schmidt, J., Wandinger, U., and Malinka, A.: Dual-fieldof-view Raman lidar measurements for the retrieval of cloud microphysical properties, Appl. Optics, 52, 2235-2247, https://doi.org/10.1364/AO.52.002235, 2013.

Sicard, M., Izquierdo, R., Alarcón, M., Belmonte, J., Comerón, A., and Baldasano, J. M.: Near-surface and columnar measurements with a micro pulse lidar of atmospheric pollen in Barcelona, Spain, Atmos. Chem. Phys., 16, 6805-6821, https://doi.org/10.5194/acp-16-6805-2016, 2016.

Sicard, M., Rodríguez-Gómez, A., Comerón, A., Muñoz-Porcar, C.: Calculation of the Overlap Function and Associated Error of an Elastic Lidar or a Ceilometer: Cross-Comparison with a Cooperative Overlap-Corrected System, Sensors, 20, 6312, https://doi.org/10.3390/s20216312, 2020.

Sicard, M., Córdoba-Jabonero, C., López-Cayuela, M.-Á., Ansmann, A., Comerón, A., Zorzano, M.-P., Rodríguez-Gómez, A., and Muñoz-Porcar, C.: Aerosol radiative impact during the summer 2019 heatwave produced partly by an inter-continental Saharan dust outbreak - Part 2: Long-wave and net dust direct radiative effect, Atmos. Chem. Phys. Discuss. [preprint], https://doi.org/10.5194/acp-2021-419, in review, 2021.

Sigma Space Corp.: Micro-Pulse Lidar system information handbook, Lanham, MD 20706, USA, 31 pp., 2018.

Sugimoto, N., Matsui, I., Shimizu, A., and Nishizawa, T.: Lidar Network for Monitoring Asian Dust and Air Pollution Aerosols, in IGARSS 2008 - 2008 IEEE International Geoscience and Remote Sensing Symposium, Boston, Massachusetts, USA, 6-11 July 2008, 2, II-573-II-576, https://doi.org/10.1104/IGARSS10663.2008, 2008.

Tesche, M., Ansmann, A., Müller, D., Althausen, D., Engelmann, R., Freudenthaler, V., and Groß, S.: Vertically resolved separation of dust and smoke over Cape Verde using multiwavelength Raman and polarization lidars during Saharan Mineral Dust Experiment 2008, J. Geophys. Res., 114, D13202, https://doi.org/10.1029/2009JD011862, 2009.

Toledo, D., Córdoba-Jabonero, C., and Gil, M.: Cluster Analysis: A New Approach Applied to Lidar Measurements for Atmospheric Boundary Layer Height Estimation, J. Atmos. Ocean. Tech., 31, 422-436, https://doi.org/10.1175/JTECH-D-12-00253.1, 2014.
Toledo, D., Córdoba-Jabonero, C., Adame, J. A., de la Morena, B., and Gil-Ojeda, M.: Estimation of the atmospheric boundary layer height during different atmospheric conditions: a comparison on reliability of several methods applied to lidar measurements, Int. J. Remote Sens., 38, 3203-3218, https://doi.org/10.1080/01431161.2017.1292068J, 2017.

Wandinger, U. and Ansmann, A.: Experimental determination of the lidar overlap profile with Raman lidar, Appl. Optics, 41, 511514, https://doi.org/10.1364/AO.41.000511, 2002.

Wandinger, U., Freudenthaler, V., Baars, H., Amodeo, A., Engelmann, R., Mattis, I., Groß, S., Pappalardo, G., Giunta, A., D’Amico, G., Chaikovsky, A., Osipenko, F., Slesar, A., Nicolae, D., Belegante, L., Talianu, C., Serikov, I., Linné, H., Jansen, F., Apituley, A., Wilson, K. M., de Graaf, M., Trickl, T., Giehl, H., Adam, M., Comerón, A., Muñoz-Porcar, C., Rocadenbosch, F., Sicard, M., Tomás, S., Lange, D., Kumar, D., Pujadas, M., Molero, F., Fernández, A. J., Alados-Arboledas, L., Bravo-Aranda, J. A., Navas-Guzmán, F., Guerrero-Rascado, J. L., Granados-Muñoz, M. J., Preißler, J., Wagner, F., Gausa, M., Grigorov, I., Stoyanov, D., Iarlori, M., Rizi, V., Spinelli, N., Boselli, A., Wang, X., Lo Feudo, T., Perrone, M. R., De Tomasi, F., and Burlizzi, P.: EARLINET instrument intercomparison campaigns: overview on strategy and results, Atmos. Meas. Tech., 9, 1001-1023, https://doi.org/10.5194/amt-9-1001-2016, 2016.

Welton, E. J. and Campbell, J. R.: Micropulse Lidar Signals: Uncertainty Analysis, J. Atmos. Ocean. Tech., 19, 2089-2094, https://doi.org/10.1175/15200426(2002)019<2089:MLSUA>2.0.CO;2, 2002.

Welton, E. J., Campbell, J. R., Spinhirne, J. D., and Scott III, V. S.: Global monitoring of clouds and aerosols using a network of micropulse lidar systems, in: Lidar Remote Sensing for Industry and Environment Monitoring, International Society for Optics and Photonics, 4153, 151-158, 2001.

Welton, E. J., Stewart, S. A., Lewis, J. R., Belcher, L. R., Campbell, J. R., and Lolli, S.: Status of the Micro Pulse Lidar Network (MPLNET): Overview of the network and future plans, new version 3 data products, and the polarized MPL, EPJ Web Conf., 176, 09003, https://doi.org/10.1051/epjconf/201817609003, 2018.

Yu, H., Chin, M., Bian, H., Yuan, T., Prospero, J. M., Omar, A. H., Remer, L. A., Winker, D. M., Yang, Y., Zhang, Y., and Zhang, Z.: Quantification of trans-Atlantic dust transport from seven-year (2007-2013) record of CALIPSO lidar measurements, Remote Sens. Environ., 159, 232-249, https://doi.org/10.1016/j.rse.2014.12.010, 2015. 